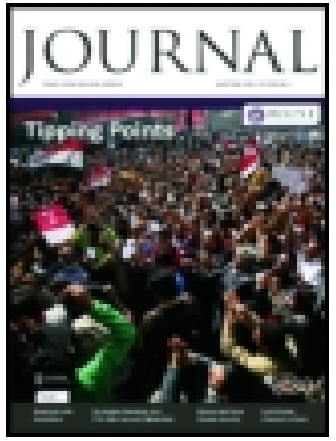

Royal United Services Institution. Journal

\title{
On Certain Roads between Turkestan and India, Independent of the Oxus, or of Any Oxus Boundary
}

Colonel Sir Frederic I. Goldsmid C.B., K.C.S.I., \&c., \&c.

To cite this article: Colonel Sir Frederic I. Goldsmid C.B., K.C.S.I., \&c., \&c. (1874) On Certain Roads between Turkestan and India, Independent of the Oxus, or of Any Oxus Boundary, Royal United Services Institution. Journal, 18:79, 469-488, DOI: 10.1080/03071847409427093

To link to this article: http://dx.doi.org/10.1080/03071847409427093

央 Published online: 11 Sep 2009.

Submit your article to this journal $\pi$

Џll Article views: 8

Q View related articles ¿ 


\section{LECTURE.}

Friday, Jane 26th, 1874.

JLaJor-Gexerag SIR HENRY RAWIJINSON, K.C.B., in the Chair.

\section{ON CERTAIN ROADS BETWEEN TURKESTAN AND INDIA, INDEPENDEN' OF THE OXUS, OR OF ANY OXUS BOUNDARY.}

Bj- Colonel Sir Frederic I. Golusmid, C.B., K.C.S.I., \&c., \&c.

WE have recently lieard here two instructire and intercsting Lectures, one on Khiva, the other on the country skirting Khira to the south ; one describing a campaign of the day, which will ever be menorable among national military anuals; the other describing a geograplical boundary line, towards which the said campaign foreshadowed, as it were, a possible movement. It is true that a line along the right bank of the Jower Orns has been declared terminal in respect of occupation; but the boundary pillar, if any be used, will hardly need a matter-of-fact inscription to serro a double purpose, and become an intelligible and expressive sign-post. And if certain definite objects, whether strategical or purely geographical, such as $\mathrm{M}$ [err and Herat, be considered especially provocatire of discussion and speculation at the present day, in connection with England's Asiatic policy, I cannot suppose that the practised eyc of the true Oriental politician will fail to rest upon those remoter parts of Tnrkestan, such as Kulja and Kasligar, where passing events are of cven more immediate interest to British India, and more sensibly affect British influence aud prestigfe.

Within the last year or two it is that, almost for the first time, we lave begun, if not seriously aud practicalle, at least with a sufficiency of light to sec our way, to look around the limits of our Indian Empire, and study as well as realise our position in respect of neighbouring countries. And it may truly be said that werer, since our earliest connection with the far East, have the immediate surroundings of British India presented so marked a combination of interests for its rulers and people as at the present moment. North and East we hare to do with China, the relations with which vast dominion are no donbt rapidly dereloping from day to das. Little was it imagined, at the outbreal:voL. XVIII. 21 
of what may be called the Anglo-Chinese mercantile war, in 1840 , or cren during the spasmodic revivals of the same dispute which culminated in the graver hostilities of 1860 , that new mutual interests, as between Great Britain and the Celestial Empirc, would crop up a few years later on that immense tract of Central dsia stretching westrard from the desert of Gobi to the Caspian. But so it is; and whether we take part or not in the settlement of difficulties which should, at least, be known to us on trustworthy evidence, neither the action of Russin or of China, nor the issue of cvents in Yarkand or the Ili districts, can he a whit less important to us than the Khiva expedition, or the determination of any lusso-Persian frontier whatever, east of the Caspian. West aud north-rest again, are Baluchistan and Afghanistan, and more remotely Persia ana Khiva. The relative political importance of some of these countries has been acknowledged in England by recent missions; and the interest which they have all more or less aroused has been erinced by discussions in the press and lecture rooms.

There may be a difference of opinion as to the propriety of agitating these questions theoretically, on the ground that the speculations arising from such discussions are oftentimes unsound; or that, even when sound and logical, their publication to the onter world is unwise. But there can be no two opinions on the propriety of gathering and recording facts on which to build a theory and frame a policy. Now, in whatever form the Central $\Lambda \operatorname{sian}$ question is presented to us, whether prefiguring an aggressive movement, or as opening ont new channels of commerce, it is clearly impossible to form true conclusions thereon, unless we know something practical and positive of distances, of people, of natural resources, and of clinate, throughont those extensive regions which now constitute the scene of interest; unless, in other words, we have correctly and minutely estimated the Central Asia of our Parliament, of our clubs, of our daily press.

I may here mention incidentally an opinion lately advanced in a foreign jonrnal, that Germany and Austria would benefit more than ing other European States by Russian progress; an opinion taking into account not only internal reforms and industrial development, but also the increased influence of Russia, on her Asiatic frontier. The writer whose anthority is given for this view, has further expressed belief in the great adrantages for German trade to bo derired from railways now under construction in Persia; and instances Khurasan as a fertile province, whose exports, maturally procecding by Astrabad to the Caspian, would henceforth be conveyed by direct railway communication. Withont densing that much of truth charncterises the theory, I doubt the soundness of the basis which alone makes it applicable to existing circumstances. It rould have been better in the first place to have ascertained whether milways are in actual construction at all in Persia: whether Khurasan is intended as an early ficld tor their use when coustructed; and to which port, sonth-enst or south-west of the Caspian, the Khurasan produce would be conveyed for export? Then, perhaps it would have appeared that both phessical and political difficulties were in the way of the desired result. Nothing easier than to 
draw across maps, lines of railway and telegraph connecting important cities or centres of commerce; but construetion must in these cases be gruided by other considerations than the shortest and most direct road, and maintenance is often a more perplexing matter still.

One step in adrance of the great Russian Empire, which, whenerer proposed, has only been publicly declared within the last few days, has too much practical bearing on the mere question of maps and frontiers for incidental mention. It is the formation of a Trans-Caspian province, bounded by the Gurgan river on the south, and by Karis, on the east; whether Kinsnorodsky be on the north or not, as stated, matters really little.

Now, should this bo fact (and we may presume it is not pure invention), the subjugation of the Téké and Yamút Turkomans has a meaning beyond self-defence and the security of present possessions. It gires power to extend territory at least as far castward as MLerv; it gires power to a smart captain or subaltern of the Imperial Army to place lis country's standard on any fortress which the subject Turkomans may have awed or controlled on their own account; and it places at command of the new settlers a rond to Afglianistan, perhaps above all other roads, of geographical and political value. To the mere cartographer such a step as this cannot be void of interest; and to thoso who follow from time to time his emondations, I commend considerntion of this latest reputed change.

My present intention is, as much as possible, to eschew theory and to proceed to facts; to learo political speculation and conjecture, and substitute a real groundwork on which discussion, if it ensuc at all, will at least bo based upon accurate data. And in order to be practical and consistent in giving effect to the proposition laid down, as well as to bring personal experience to bear upon its treatment, I will submit a brief account of two roads between the Caspian and the Lower Indus, one commencing at Enzeli, the senport of Resht, and terminating at Kurachi; the other commencing at Jacobabad, above the old Sind stations of Sakar and Shikarpar, and terminating at Bandar-i-Gez, the seaport of $A$ strabad. The one which may be reckoned, in round, but fairly exact numbers, at 1,870 miles, comprchends a section of the north and the whole breadth of Eastern Persia and Persian Baluchistan, together witl the coast of Eastern MIakran, under the sovereignty of the Khan of Kelat. The other, estimated at 2,020 miles, is through a large portion of Lower Afghanistan, and includes a considerable tract on the north, as well as east of Persia. The first of these roads I have traversed throughout; of the second my personal knowledge permits me to speak of about a thousand miles onl $y$, or from the Helmand to Tehran; but Dr. Bellew's careful journals of the marches of Sir Richard Pollock when procecding to join my camp in Sistan, little more than two years ago, enable me to supply lacuna in personal experience by late and trustworthy authority. I may premise that any want of pure military colour in the picture, or absence of professional technicalities, must be attributed to the nature of the subject. For it need scarcely be submitted to the members of this Institution otherwise than as a truism, that the data requisite for determining the 
passage of armies lavo a specjal signiticance also in a general and commercial aspect.

The high, steop and narrow mountain pass which defies the heavilyburlened or lightly-equipped soldier, if erowned with hostile marksmen; the waterless waste scorched by summer heat, or swept by bitter blasts of winter; or the constant and continuous lack of grain, fodder, or provisions of hinds for man and beast; are facts of equal importance, though in lessser degree, to the ordinary cararan, as to the columns of an army.

Salient points such as these it is the province of erery trareller to note, in patting forward the result of his obserrations; and if with all their military speciality they wear a sort of civilian guise on the present occasion, their appearance will, it is hoped, be justified on the plea of foreed association witl genernlities, and that whole mufti is preferable to a mixed costume.

The road from the south-west corner of the Caspian to Kurachi may be divided into four sections:-

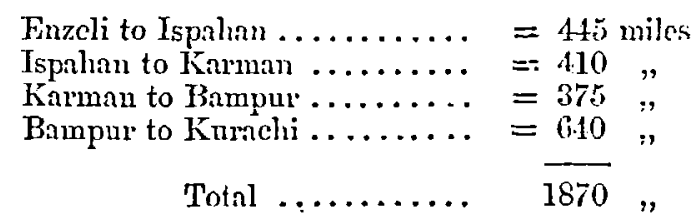

The first section is over a part of the country better lnown, perhaps, than any other to Enropeans. Less than midway is Tehran, the capital; close to Finzeli is the large town of Resht; betwcen Resht and Tehran is the city of Kazvin, and between Tehran and Ispahan are the cities of Kúm and Kashan.

From Enzeli there are about 40 miles of forest land to be traversed in the province of Ghilan. The Jow level of this fertile tract makes it feverish and nnlealthy; but shelter from hent and ample sipplies are, on the other hand, very important considerations, and both, for the distance giren, may be depended on. But nlthough villages, trees, and cultivation are not lost sight of after 40 miles, the aspect of the country changes; and lanes and forest are exchanged for the brond bed of a river and marrow artificial paths along the mountain scarps, or rongh arbitrary tracks at the foot of orerhanging hills. Much of the conrse pursued by the ordiuary traveller depends upon the depth of water in the rirer, and like uncontrollable conditions; but at about 60 miles from his place of disembarkation from the Caspian steamer. he has cleared all dense forest and regetation, and risen upon a more open and genernlly sterile country. For the next 50 miles lis journey is over the barren mountains dividing Ghilan from Irak to the Kazvin plain and city, and one pass is a stiff one indecd. The more fact that in two marches, or from Rustamabad to Kharzan, the rise is from almost the actual sca level to a height of 9,000 feet, will suffice to show that here, as in the south, the change from the fringe of sea-board to the high Persian platcau, is not an insignificant item in a common place journey. Now it is, I believe, proposed to conncet Enzeli and 
Kazvin by rail, and Baron de Reuter's enginecrs have been engaged in ascertaining the best line to be chosen for the accomplishment of this important object. In any project put forward it is presumed that superfluous ascents and descents will be avoided, and the connection effected by a less formidable course than that hitherto pursued by caravans; but the one stubbom truth remains that the platean must bo reached from the seaboard, and that this ploteau, at its lowest, has an clevation of some thonsands of fect.

The road from Kazvin to Tehran presents no plyssical difficulties. It is over 90 odd miles of plinin country south of the Elburz range. Whicherer track bo chosen, the mountains will be on the left, and the face of nature will present much the same aspect. The sky and the hills are charming; but tho landscape is monotonous in colour. There is, as it were, one universil coat of drab, or lihali (as better expressed in India); villages and gardens are the darker patches and streaks upon it. A distance suel as this, being less than a hundred level miles, with a populous town at either end-one the capital of the kingdom-need arouse no appreliension on the score of supplies, eren though interrening population and cultiration be scant. Water should be procurable at all scasons from the near mountains. At Kirij, abont 30 miles west of Theliran, there is a river.

The tro main features in the high road from 'lehrau to Ispahthı atre a desert of some 40 miles' duration, and the passage of tho Kohruid, a mountain of 900 feet in height from the sca level, but fir less from the platean. Of the first I may say that, however near it is to the capital of Persia, the spot is very suggestive of isolation from a peopled world. There are cararanserais in the way which mas afford shelter from sun or blast, but it is well to place no dependence on their supplies of grain or water. It is ealled by the natives the "Valley of the Angel of Death ;" and aptly does Mr. MLounse5, one of our latest and most agrecable authoritics on Persia, sny": "No other name conld "better indieate the dreariness of this region. It is a succession of " narrow gloorny glens, shut in by parched rolcanic hills, through " which the path runs over alternate patehes of nitre and movable " saud. Not a blade of grass, not a solitary herb erer grows in its " lifeless salt-sown soil." " Of the second, except in winter, the passage is not hard or intricate; and in summer, or during the great heat of the plains, the climate of the presiding village and higher tracts is most invigorating. Before ascending from the more northerly side, the large towns of Kím and Kashan are guarantees for supplies; and after descent on the south, the road to Ispahan is over a tolerably level country which, if generally dreary and desolate, is at least occasionally relieved by rillages, caravauserais, and cultivation, and improves nuch towards the close.

'The next section of 4:10 miles, from Ispahan to Karman, differ's little from the last in lespect of the large amount of desert and limited portions of cultivated laud. But the road is of a much easicr description, and one which might be traversed by carts and carriages as well as

" "A Journey lhrough the Ciucusus uul Interior of Persia." Smith, Elder, and Co., 1572. 
horsemen. Some hills are met with about 60 miles cast of Ispahan; and these appear to belong to the Kohrud range overlying the lehran road, but thes are comparatively low, and might, it is beliered, be aroided altogether by the traveller from the capital, who prefers a short and direct route to Yezd from Kaslan. Irrespectivo of these hills, it may be said, without exnggeration, that the whole country from Ispalun to Karman com be driven over, for the most part, by a coach and four; only supplies are scarce in some places, and quite unobtainable in others. Between Ispahan aud Yezd there are 50 miles of decided desert, and betricen Yezd and Karman, the eecond and larger lalf of our entire section under consideration, there are more than 70 miles of like charncter ; nor is the rest of the way over a purely fertilo country, except at long intervals, or near centres of commerce and cultiration, such as the two prorincial capitals last named, or the rillages of Anar, Bahramabad, and perlaps Minhammadabad, south of Yezd and north-west of Karman. One of these, Bahramabad, has of late years attrined more than local importance, its productivo resources having drawn thither the Hindoo trader from his mative home more than a thousand miles away. There are very fine ranges of mountaius seen at Yezd, and along the lines of traffic to and from that city: otherwise the general aspect of the landscape is flat and mouotonons. The cararanserais are numerous and good. There may be occasional insecurity for single travellers or small bodies passing along the beaten track forming the highway; but an armed escort need not be large, or especially well equipped for purposes of self defence or to ensure immunity from all attack. Bakhtiaris and Baluchis are the reported marauders of these points; but a vigorous government could readily put a stop to their mischief if they wero to set about the procecding in enrnest.

The third section of our journey is of 370 miles from Karman to Bampur in Baluchistan; and this may be described briefly but in detail. From Karman to Mahmm is over a barren tract of 20 odd miles; but Malmn itself is a flourishing rillage with more than 1,000 houses and mauy gardens, and should not be wanting in supplies. From MLahun to Rain, more than 40 miles, is chicfly over a mountainous and dreary tract; but here again, Raiun itself is not a bad kind of yillage, though with hardly half, perhaps no more than a third of the population of Mahun. From Raiun to Bam, 24 miles, cultiration is very sparse, and waste land abundant, but there is undoubted fertility in the 'Iahrud arrondissement, which may be traversed in the way. Bam is a large town, and remarkable for its gcographical and strategical position, as well as for its fortress. A word, howerer, on this place will not be irrelevant.

In 1810, Lieutenant Pottinger, trarclling in liazardous disguise from Sind to Shiraz, passed through Narmashir, of which Bam is now the capital.

'The Ghilzai Afghiaus, who had colonized it for' ncarly a century, had been dispossessed of the district only seven jear's before, so that the political stetus was one of transition. Bam was then the frontice town of the Karman province, and its fortifications had been so strengthened 
to resist continual attempts at its reduction, that they were accounted "bejond any comparison the most defensible in Persin." Pottinger thus briefly describes them: "They "are an elerated site, and at pre" sent consist of a very Jigh and thick mud wall; a deep, broad, and "dry ditch, with six large bastions on each face, exclusire of those at "the corners, which are higher by many fards than the others; the " whole is built of mud mixed with straw and fibrous substances, and "there is one gate between the two centre bastions of the southern " face. The citadel is on the highest part of the enninence on which "the town is built, and is well fortified with a lofty wall and towers " at cach corner"; the arca thus enclosed, is entirely occupied by the "Governor's palnce, and buildings belonging to it."

In his description of the town the same authority speaks of the ruins and gardens as testifying to the existence of a much larger place. Officially rererting to this after my first visit in 1866, I added: "Since "he (i.e., Licutenant Pottinger) wrote, it has been the scene of an " international struggle, which, added to an carthquake, resulted in the " almost utter" destruction of the town within the walls. Nearly thirty " gears ago the Commander" of the Shah's Arms besiened there the "well-known Agha Khan Mehlati, then a rebellious Governor of Kir" man. The fort was held for more than a jear against the Royal "troops. The shot marks in the walls prove that the matter was in " carnest, but the capitulation appears to have been peaceably effected. "It is now satisfactory to see that the more moderu town, such as it " is, can be built independently of fortifications. Estimating the " houscs to be about 2,500, and the population 10,000, I should say "that not one-twenticth of the inhabitants live within the walls. In" deed, it seems to me that no residents are allowed there but the garri"sou and families with a few rendors. Through the lindness of the "Gorernor of Karman, who gave me an order in his own handwriting " to the Commandant, I was admitted to an inspection of the fort, a " really interesting illustration of Oriental architecture. Pottinger "mentions but one gate. That one is doubtless the same as that by "which I entered, and leads by the main street and bazaar to the " citadel. I am informed that there are two other means of ingress " and egress, but saw one gate only. The citadel appears to be par" tially built upon natural rock, and is prorided with a well of drinking "water. I learn that there are two companics of infantry and a few "artillery kept in garrison here. $\mathrm{M}_{5}$ impression is that thesc com" panies cannot be reckoned at their full strength, and that there may " be 20 gunners. The towers were alive with red coats, and abont 15 "artillerymen were drawn out, under a Naib or Lieutenant, to carry "swords as we passed towards the citadel ; hat what description of " ordnance, if any, was under the large white cloth thrown over the "two gun carriages I cinnot determine. The men were generally "well dressed and smart looking for Persian soldiers. An instance of " smartuess may be cited in the direct refusal of a sentry to admit mo " to the fort without a witten order. It so liappened that we had " walked away from my lodging without bringing tho essential docu. " "Trarels in Baluchistan and Sind." Lougman, 1806, p. 201. 
"ment. The sentry placed his musket horizontally across the half of "the gateway which he could so protect, and his comrades filled up " the other half. On my expressing approral of the man's conduct, "one of onr party came up and assured me that the Yiuvar, or Major " commanding the fort, was one of the finest Officers in Persia, insin" uating that the proof of discipline just witnessed was the result of "eflicient supervision." "*

I have revisited Ban twice sinee the oceasion in question, first on going to Baluchistan in 1871 , and sccondly on my way to $\Delta$ fghanistan in 1872. Neither time had we the chance of proving the smartness of the sentries, for the higher grales were inllexible in refusing admittance within the fort walls to any member of my staff; and I did not press it on uny own account, being engarged in an independent political mission of some delicacy. But we were without the. provincial Governor's order which had been voluntarily accorded me on my appearance as a plain European travcller: and this want might naturally be supposed fatal to the accomplishment of the desired object under any cireumstances.

Bam is conreniently situated in a highway leading to Karman, Sistan, Bampur and Bandar Abbas respectively. 'The Karman road is also that to the capital, Ispahan and Shiraz. The Sistan road is that to Khurasan and the Caspian. Bampur is a gate, as it were, to Baluchistan and Makran; and Bandar Abbas is tho sea-coast. MIy latest impression causes me to reduce the former figrure of its fixed population to, at most 6,000 ; but has heightened rather than lowered my estimate of its geographical and strategical importance. 'It is said that the regiment stationed here is always from Telman; and that vice verat, leries constituting a Bam regiment would be sent to the capital.

Firom Bam to Regan is a distance of 60 niles, whereof two-thirds is through a country which descrves to be called fertile in Eastern Persia, however opposite the character it would obtain in our own land. I beliere that, under a good Government, and with an accession of desirable immigrants, the second condition being a sure result of the first, this district of Narmashir might become a granary of no mean resources and extent. It is now rich in farms and grain ficlds, and is profusely intersected with canals and watercourses. For some fow miles before Regan, and beyond Regan to the Bampur Plain, 100 miles in all, it is almost unbroken desolation; and there are four marches amid barren rocks, which, if not steep and hard of access, are tortuous and pathless enough to perplex large bodics at all scasons, and might, in summer, be simply impassable. The Plain itself is easily trarersed, but water and supplies are scarce, and no villages worthy the name interrene until within 10 miles of Bampur.

This place can boast of some 400 habitations: of these, the Governor's aud two or three more may be called houses. The fort is built on a long irregular mound, north, and on the ligher side of which is the citadel, whence the walls run down in a southerly direction. There were soldiers and guns inside when I was there in 1866; but

* To Secretary to Bombay Gorcrnment, dated 17th March, 1866. 
the camp was ou the plain below. $\Lambda$ detachment under a Surleruet, or Lieutenant-Colonel, had arrived a day or two bcforc me, but had taken a ronte north of mino from Regan, falling into my road at the last stage into Bampur. The drum, bugle, and word of command were constantly heard near my quarters. In 1871 , when a sccond time at Bampur, I had the benefit of these daily sounds for more than a fortnight, and can answer for their bearing very close resenblance to those of a natire Indian cantonment.

From Bampur direct control is exerciscd orer the districts which are conprised in Persian Baluchist:u. It is only within the last trenty years or so that any attempt has been made to consolidate these; the main object having been to add to the number of suljects and extent of territory under the Persian flag. The custom las been to inveigle or compel as much as possible the more influential Balnch chiefs to acknowledge the sovereignty of the Shah, and as fiast as one was grained over, to employ him in bringing in auother. The net rather than the sword has been the means usnally employed to gain the desired end; but when this was found to fail, force las been adopted. Then I was first at Bampur, the work of subjugation ras proceeding with rigour; and the resistance which it occasioncd rendered the conutry somewhat insecure. It is to be hoped, now that Persia has anreed to restrict her encroachments within a fixed line, she will turn her attention to a system of interual administration more calculated to content lier Baluch subjects than heretofore.

Next for consideration is the road from Bampur to Kurachi, estimated at 610 miles; and here we have reached by far the most dificult scetion of the whole route attempted to be described. The Persian soldier, or sarbaz, capable as the is of marching continuously for extraordinary distances, and endowed with powers of physical cndurance astonishing to Europeans, has been scldom sent for actual fighting purposes throngh the Mrakran passes to the sca const. There is a chain of hard, steep, rugged rock which fences the highland of Bampur from the descent to the shores of the Indian Ocean; and once through these passes, all inmediate help would secm obtainable from the sea. It is no casy matter to penetrate this corlon at all. I hare tried two ways of egress; one by Sarbaz, and so on to Gradar; anotlier by a more westerly route through Fanoch, to Charbar. The first is the better adapted to our present purpose, being only 20 miles longer than the second, reaching a point 100 miles nearer Kurachi, and passing, perhaps, through a better description of country. Sarbaz is, to all appearance, a more hourishing place than either Faroch, Bentl, or Dehan; and Pishin and Parúd may be found useful halting-places; but it is absurd to suppose that any of them lare material for provisioning an army. A demand for supplies to a detachment of 500 Persian soldiers would throw the whole country inito utter confusion.

And if the dilliculties of moving from Bampur to Gwadar be great from the causes last adverted to, what must they be for the 390 miles of barren coast from Gwadar to Kurachi, so far as the inland resources are considered? Setting these aside, or admitting the co-operation of ships for purposes of provisioning, the physical obstacles of country 
would not be orerpowering. For the greater part of the way, a good beach, or a road near the beach, and below contiguous hill ranges, is to be found; the most scrious interposition being that of a line of almost perpendioular cliffs actually dipping into the sea, with no definite path at all for fire or six miles. How to pass the "Malan"-undoubtedly the Malana of aucient writers-was the first really hard problem which presented itself to those Eurlishmen who set up the Makran Innd Telegraph in 1862-63, working from the castward. It was solred by a long span from the beach to the top of the cliff, and by carrying the line orer the level space above to a point whence it could drop, and again find its way along the sen shore; but the process could ouly be effected by getting tons of iron posts and wire up 2,000 measured feet in height. Such a road could clearly not be attempted by a marching body, however small, who, to clear the Malan, would hare to make a 40 mile clétour; as I myself did with an escort of Sind Horse, by a zigzag passago among stecp mountains. Mr. Waltou, Director of the Makran Const Telegraph, wrote to me, when completing his work at Gwadar, in April, 1863:-" I need not tell yon of "the physical difficulties of the country wo have come through. The " want of water in many places has driven us to endure great liardships. "A body of 25 Europenus and 600 natives passing through this utterly " barren country must expect to meet with rery great difficulties. "Often I hare been obliged to prolibit ablutions of any lind, and to " place guards with drawn swords over dirty puddles. Of course, all " liad to be fed from Kurnchi, and the posts being all of iron, brought " from England, were distributed eighteen to the mile, and required "many camels, which were likewise almost entirely supplied with " provender from Kurachi."

The aspect of tho country traversed is indeed desolate, and the inlabitants are few. Tet are there gems of wild, romantic scenery to be discerned among the Hinglaj mountains, especially in the approach to the shrine of the Hindn pilgrims. Fixed population is almost entirely concentrated, as a rule, in the fishing villages, such as Sonmiani, Ormara, Pasni, and Gwadar. The nomads are found occasionally in small bodies, where there is cultivation, water, or other life-sustaining attraction, and their presence is invariably signified by the use of the word "lihalk," i.e., a collection of human beings. Cultivation, howercr, except at the villages, or in their immediate precincts, can hardly be said to exist. Fodder for cnttle is chiefly grazing for camels, and even this is not always procurable. When I marched from Knrachi westward in 1861, wo laid in a stock as best we could. Water was, upon the whole, sufficient for the wants or our party, and we rimmbered more than 60 , inclusive of Europeans. t $^{-}$

As regards the water supply, lowerer, I kept a record for every nuarch, and attach a copy to the present paper for reference if required.+ But in this respect very much depends on the seasons, and I have

- "Proceclings of Royal Goograplicul Socicty," rol. rii, 1862-63, p. 47.

t I may be prirloned for repeating hero wy own worls in "Telegraph aud Irarel" (p. 6 6 $\geq 0-21$ ) now under publication.

Isco Appendix. 
little doubt that a rainless year or two would be severely felt on the Makrau const. Of the lileaurs, or salt water crecks, which, met by mountain torrents from inland, form the months of rivers, I ofticially reported the names of no less than 27 between Sonmiani and Jask, a distance of 700 miles. Half the whole number I had myself traced. The beds were in many cases of considerable width, defined by high, steep banks, which at times receive large rolumes of water, and become on the sea side often accessible to smaller craft. Were the coast road to be put into civilised order, bridges would be in frequent requisition.

But the last and most material fact to be borne in mind, as comected with this particular ronte, is the facility with which British India is cntered from the westward. There are no steep monntain chains to be traversed; no rugged passes or defiles to be threaded to change the scene from Baluchistan to the valley of the Isower Indus. Whatever obstructions or dangers may bo anticipated in the Khaibar or Bolan; or whaterer objections may be raised to the use of less frequented passages throngh the Sulimania range, or the still wilder mazes which shut in Sind to the westward, nothing of the kind is apparent in the cass bend of the coast which turns the angle formed by the Indian Peninsula with the Baluch seaboard. And from Sommiani to Kurachi the lill ranges intervening hare become, as it were, expended in importance, and are no longer of any formidable lieight, extent, or stecpness. The only approach to a pass is called the "Likh Badok," whence the descent to the lower ground leads at once to the $\mathrm{Hab}$ rirer, which marks British boundary.

In further illustration of Eastern Makran and the coast, I quoto from an old report submitted to Gorermment on the occasion of my mission there in 1861, a few passages which may be found of interest:-

"A regiment marching with commissariat along our route would no "doubt be put to great shifts for supplies, if dependent on the country. "The least scaree article of ordinary consumption would perhaps be "meat. Sheep and goats are not wanting near the sea. Grain is " scaree indecd, and would have to be carried. There is a tolerable " market for necessnrics at Soumiani and Gwadar, one somewhat in" ferior at Ormara, and none to be depeuded on at Pasni. Ormara " and Gwadar, the first especially, were rather exorbitant, but this is " not surprising, and the occasion was not one to demur.

"The forage procurable was not always nutritious, but it never "actually failed; and the horses, with little exception, kept exccllent "condition throughout the seren weeks of onr march, and indeed up " to disembarkation at Kurachi. As a rule, I think, the camels were " better off" in this respect than the horses. W'hey nerer were without " fodder of some kind, and often found it of the very best description. "Beyont Ormara the date palm became inore and more frequent, the " babnl and tammisk continued to thrive, and the wild grasses and " vegetation of all sorts can scarcely bo said to linve dininished. Per"Laps no better or" more abundant grass was discovered than near tho "sea beach leadiug to Gwadar. Cultivation was indeed rare, and no. 
" where but in small patches. It may be limited to wheat, jourace, " siroo, moong, and cotton, exclusive of the plots of garden at Gwadar " and near Sommiani. The cotton I remarked at the back of the Kapar. "promontory. In many places in the Kolach district are 'bals,' o!" "plantations of palms, marked off by artificial bauds, coustructed to " retain the rain water."

Such, then, is the connty for the 1,870 miles between Enzeli and Gwadar. The distance might be diminished by following, here and there, a more direct track than that laid down; but supplies would be less certain, and more obstacles to progress would arise. In Makian I beliere the const line to be the best, because the parallel valley:s iuland offer no ready access to British India. The passes into Bélir and Sind would present very grave difficulties. We cannot contemplate the successful passacre of an army, according to the European aeceptation of the word, through even a third of the whole distanee named; unless, indeed, the whole resources of . Persia and Baluchistan were combined for its provision, and the inhabitants, one and all, not merely disposed, but determined, to make its way smooth.

I feel compelled to differ from those who cite the conquests of Nadir Shah, more than a century ago, in example of what might yet be done by any possible invaders of India. The prestige of this eastern Napoleon was, it must be remembered, immense. It had not only reached, but had been keenly felt in Delli before the conqueriug amny had arrived. There was no actual religious war-the contest was between vigorous M[nhammadanism and effete MLulıammadanism. Nadir had not, like Casar, come and seen, when he had conquered. His was had been prepared by circumstance, and as he progressed from day to day, his army of invaders increased. There must have been more accessions by voluntary recrnits than decrements by death or desertion. A Kizilhash in his camp reported from . Inlalabad: "Ho has 36,000 liorsemen "with limself. $* *$ After moming praycrs he sits on a " throue, the canops of which is in the form of a dome, and of gold. " 1,000 young men with royal standards of red silk, and the lance tops " and tassels of silver, are disposed regularly, and at a proper distance. " 500 beautiful slaves, from 12 to 20 years old, stand, one-helf ou his " right land, and the other on his left. All tho great men stand "fronting lim; and the Arzbégi stands between, in reacliness to re" present whaterer he is desired, and everybody lias his cause decided " at once: bribery is not so much as known here. He has particular " information griven him of everything that passes; all criminals, " great and small, rich and poor, meet with immedinte deatl. He sits "till noon, after which he dines, then reposes a little; when after"noon pragers are orer he sits till the evening prayers, and when they "are over he shoots five arrows into the Khicl. 'T'udal, and then gocs " into the women's apartmonts." *

This kind of picture is, I think, inapplicable to these more practical times, when eren the imaginative Oriental nind is prone to accept matter of fact limitations to the pomp and power of Oriental heroes, testing their significance by lard but leenlthful comparisons.

* Frater's Saclir Shah : edition 17.2, p. 1-12. 
The country we lave last gone orer is, however, mainly interesting to us by history more ancient than that of Nadir. It is the gronnd trarersed by Alexander and his Captains on return from India, while Nearchus was moving his ships along the sca coast, leisurely enongh to take note of harbours and landmarks. Names now extant in Makran may be readily identificd with those mentioned by Arrian and the geographers Strabo and Ptolemy.

As regards the people, I do not believe that those who, from less frequent contact with Europeans and comparative remoteness from the so-called civilization of a capital town, are held to be the rader classes, are so dangerous or inveterate in their prejudices with respect to foreigners as their more polished brethren. The cultivators in Persia may be reckoned pencefil as the fishormen of Baluchistan; but the Persian who does not settle down to agricnlture makes a hardy, frugal, and enduring foot soldier, or a smart, bold, and intelligent trooper. The caralry in Karman and Baluchistan is not by any means to be despised. Lightly armed and cquipped, thes appear well adapted for the scrvice required at their hands, and if this be not precisely what is expected from European dragoons or chasscure, it is not necessarily of a subordinate clanracter in military parlance. The Baluch of the hills is naturally a fighting man, but neither in material or pluck can I call him superior to the Persian. There would be no lack of good soldiers from Kurnchi to the Caspian if there were only available the skill and patience to discipline and turn to account the raw material.

Now to review briefly the route from the Sind vorder to Kandaliar, and thence to the Caspian through Sistan and Mashlhad. This I have reckoned at 2,020 miles, according to the road taken by Sir Richard Pollock and Dr. Bellew. Jacobabad, whence the start was fairly made, is, I nced hardly explain, a flourishing military frontier station, formed by the distinguished Officer whose name it bears. I myself became first acquainted with it more than 20 Jears ago as Khangarh, but it lind then fairly entered its transition state, and was not, as others may remember it, an obsckre and insignificant collection of huts on the Sind border of the desert. It is 28 miles from the large town of Shikarpur, which again is 24 miles from Sakar, on the Indus. Three miles on its western side is the present line of British frontier.

I propose to divide Gencral Pollock's journey to Bayjar, in Sistan, the point at which he joined my camp, into two sections-

1 st, one of 515 miles, from Jacobabad to Kandahar; and,

2ndly, one of 425 miles, from Kandahar to Sistan.

From Banjar, whence we all moved together to Tehran, I make the two remaining sections, one to Masuluad of 580 miles, and one to Bandar-i-Gez, S.E. of the Caspian, of, roughly, 400.

Without attempting to describe my own journey from Bandinr $\Lambda$ bhas to Sistan, in which province I remained through the whole month of February and part of March, 1872, I take up the record of the party about to enter Afghanistan.

Their first march was one of 35 miles, to Bashori, a village of 80 houses, with corn cultivation, but a precarious water supply, across a 
desert well described as presenting a "wide smooth surface of hard "dry clay, level as a billiard table, hare as a board," without a pebble, a blade of grass, or any distinguishable feature but the caravan track. From Bashori there are two roads to Kandabar, one north to the Bolan by Bagh and Dadar, another west, by Gundara, to the M[iloh Pass. The closing of the Bolan rendered compulsory the selection of the latter, thougli the longer by 190 miles. In eight marches our party arrived at Khozdar, a distance of 125 miles from Bashori. For the first 40 miles to Kotrah they moved over a level and partially irrigated tract, passing the fortified town of Gundara, for the rest of the was the country being "dreary, desolate, and wild."

According to Bellew, "mountain follows mountain in a monotonous " snccession of bare, rugged rocks, which, even in the winter midday " sun, radiate an uncomfortable degree of heat; whilst dale and defile " succeed each other, with no more striking feature than their" wild" ness and poverty in the one case, and their rugged narrowness in " the other. In the whole distance from Kotrah to Khozdar there are "but two permanent habitations, about thirty houses in cach." The Miloh, better known as the Moolah Pass, may be said to extend from Pir Chatta to Gaz, a distanco of about 50 miles, is easy, well wooded and watered, and presents no physical obstacles; "the ascent is very gradual, the rise being about 3,350 fect." Klozdar, though it occupies an important position on many maps, is no town, but possesses a recently built oblong fort with bistions, loopholed and crenelated curtains, wanting, howercr, a ditch. It has two guns, and a garrison which may be reckoned at 150 men, artillery and all included. The valley of Khozdar is one of the principal corn-growing districts in the whole country.

From Khozdar to Kelat is about 100 miles, by a succession of tablelands, separated by low ridges rumning east and west, and rising gradually one above the other up to 2,850 fect. So that while an ipproximate clevation given to the former made it 3,850 , the latter was recorded at 6,700 fect. When our trarcllers passed, the whole tract had a dreary look; but in summer the pieture is said to be reversed. Water, however, is scarce.

Kelat, capital of the state of that name, and licad-quarters of tho Khan, is a fortified town, bnilt at the extremity of a ridge of bare rocky hill, and on the plain at its foot, with 3,500. honses, and some good bazanrs. The valley is populous, and highly cultivated. There are many villages and walled gardens clustered together east of the town, the cultivation is rich, and water in abundance from numerous springs in the adjacent hills, and from a large clear stream that flows on a pebbly bottom past the enstern side of the town.

From Kelat to Lora Kushlak, 119 miles, the route is through a narrow, diffienlt, and stony pass, called the Laghani Kothal, into the Mungachar valley, with its cultivation and fortified viljages, thence up a moorland tract, between mountain ranges and over tho Lower Mastung allurial plain, to the Aman Ullah stream, nine miles beyond which is the fortified town of Mastung, having a thriving bazan, and 1,200 houses, and placed "in the centre of a very populous and fertile 
" valley." It is worthy of mention that here the gardens produce "the "apple, apricot, plam, cherry, quince, powegranate, almond, a variety "of grapes, and the mulborry;" while the fields have "wheat, barles, and maize, luceme, madder and tobacco." The course was next through corn-ficlds, followed by a sandy tract and a gradual ascent up to the Neshpa Pass, estimated at 6,000 fect. On the west of this was observed the high snow-covered Chahltan, and east was a lower range. The descent was gradual over a rough stony surface, and led to a road shirting the vast plain kwown as the Dasht-i-bedcolat, and thence to the Shal valley at Sariab. Dr. Bellew's own words will be liere interesting :- -

"The valley of Shal is very populous, and highly enltivated, the "fields being irrigated from numerous Karez streams. The soil, how" ever, is ver'y strongly impregnated with solines. Tho fort, Kwatta, as "it is called by the Afghans, ccenpies the summit of an artificial " mound, and wears an appearance of decay. Around it lies the town " of Shal, enclosed by fortified walls. It is about the same size as "Mastung. 'I'he garrison of the fort cousists of 100 infautry, mostly "Afrhans, and about 40 horsemen; there are also a few artillerymen, "who take care of the single guu here." Another 16 miles brought the party to their next station, havingr been met on the way by their Afglian escort, who had come thus far to relieve the Kelatis, and under whose charge they threaded the narrow Murghi-tangi gap, whence, by a stcep descent into a glen, they reached the valley of Kushlak.

From Kushlak to Kandahar city is about 135 miles. This distance was accomplished in nino stages, arcraging 15 miles each. Part is over plain country and cultivation (in which section the names of the Peshin valley and villages of Haidarzai and Haikalzai will readily be recalled to mind); part orer rugged and nndulating tracts; part again inrolves ascents and descents, and working through passes rendered in winter especially difficult by frost and snow. The fourth march over the Churga Pass, clearing the range familiar to us in Indian military history as the Khojak, was ono of seven miles only. 7,400 feet above the sea is the approximate cleration recorded for the summit.

Kandahar necds no new description; but the latest estimate of the population may be interesting. Of the reported 5,000 houses, one-fifth are unoccupied, and the number of inluabitants is reckoned at 15,000. "The district contains upwards of 200 villages, ranging in size," according to Dr. Bellew, "from 30 to 350 houses." Estimating the district village by the town houses, the result wonld show a district population of more than 150,000 .

The distanee from Kandahar to Kaleh-i-Bist is nearly 100 miles, and was divided by our travellers into five stages. Passing anid corn fields, canals, walled gardens, and villages, and skirting the hills on the left bank of the Arghandab, they crossed that river to a tract of a similar character on the right bank, then following its course generally until they reached a point where the roid bifurcates, leading due west over a desert country, and west-south-west along the Arghandab. $\Lambda$ general direction of west by south, with an occasional zigzag in 
detail along the bank, brought them to the left bank of the Helnand, and crentually to Kalch-i-Bist, situated just above the junction of the two rivers. The sources of the Helmand and its tributaries must bo looked for among the mountains of the Hazarch and wild little-explored regions between Herat and Kabul. 'The Koh-i-Baba is said to mark the actual rising point of the main stream.

Dr. Bellew reports as follows:-

"The country from Kandhlar to Kalch-i-Bist is for the most part " waste land, and void of water. The course of the rirer for a width " of four or five miles is populous, well cultivated, and irrigated from " numerous canals, but all to the north of this tract is a wide waste. "Many of the canals are deep and narrow, with high banks. Where " not bridged, they offer serions obstrnetion to the traveller" with laden " cattle. With a little labour, however, they can be casily made pass" able, witlont obstructing the flow of the water. This is effected ly. " anmping down the sides, and filling the bed of the stream with "fascines of the thorny bushes growing on its hanks, by which pro"cess the stream, instend of being a decp and narrow one between " high banks, becomes a broad and shallow one between gradually "sloping banks."

From Kalch-i-Bist to Rudbar, a distance of 200 milcs, the route is along the left bank of the Helmaud in a southerly and south easterly, then westerly direction; and the greater part of it, that is, from Hazarjuft, the first station, a long march of 40 miles, to Rudbar, is called the Garmsir, or hot region. There is a good deal of pasture land and of cultivation, and there are many villages and huts of armed tribes found on the way; but there is also much waste land, and there are many tedious and unproductive sand hills. 'The Helmand is in parts from 250 to 300 pards broad; in parts as much as two miles. The chamnels are either dispersed, or forni into a single stream of about 80 yards in breadth. Dr. Bellew's record shows that Rudbar was reached in ten marches from Kalch-i-Bist.

From Rudbar to my camp at Banjar the travellers from $\Lambda$ fghanistan made the distance, in a somewhat circuitons course, about 125 miles, of which 100 were, as it were, in continuation of the road to Sistan, down the left bank of the Helmand, and 25 miles were through the lavishly irrigated and fertile lands of Sistan Proper, or Persian Sistan.

Having joined camps at Banjar, from this point we marched all together to Tehran. There is no need to describe the intervening country for the whole distance, as at Shalrud the road branches off to $A$ strabad and the sonth-east corner of the Caspian. From Banjar to Mashlad, the road northward to Lash, a fort and village on the Farmh river, is over the reeds and dry bed of the so-called Hamún or Sistan Lnke, among ruins and little-peopled tracts. From Lash, northward again to Kalehkah, the villages and cultivated spots are scarce; and the change of course to the west and over the Harud river is to utter desolation, more or less relieved as the village of Duruh is approached. Hence to Birjand the country is a succession of mountains and valleys, but the road is easy eren across the passes, 
there aro tolerubly flourishing villages, and cultivation is not quite wanting. Birjand is a tolcrably large town of 12,000 inhabitants, nearly $\tilde{5}, 000$ fect above the level of the sea, the modern capital of the large Kíian clistrict of Persia. It is abont 250 miles from Banjar. Between 60 and 70 miles to the north is Káian, the old capital, to reach which we made four very pleasant hill marches, one of which gave an eleration little slort of 7,000 feet. From Káian to Bajistan, 90 odd miles, our course was among mountains and across plains; frequently also skirting plains aud hugging the mountains, to keep in with the richer villages and cultivation and aroid the Turkoman marauders. 87 miles further over a yenerally desert countrs, dotted with an occasional village, and prescenting to vicw to the west the great salt descrt of Khúrasan, wo came upon the town of Turbat-iHaidari, which is the centre of quasi abundance, whether of grain, fruit, or vegetables. Hence to Mashhad, 82 miles, there is plain, mountain, and plain again, with sparso cultivation.

Mashluad is a city with 70,000 inhabitants, the capital of Khnurasan. Hence to Shahrud, a distanco of 290 miles, the high road pisses through the large towns of Nishapur and Sabzawar, and one flourish. ing village called Melnr. Set aside the vicinity of these places and the mountainous 30 or 40 miles between MIashhad and Nishapur, and the journey is desert and monotonous, for the most part through a tract infested by plundering Turkomans. Shahrud is a town of 8,000 inhabitants, whence there is a road to Astrabad, which is reputed to liave 18,000. The distance between the two places is only 75 miles, but there are three chains of mountains to be trarcised, one of which, the Vijmann, is estimated at 9,250 ; one, the Jilin-Bilin, at 7,420 , and one, the Ali-abad, at 6,525 feet in height. From Astrabad the road to Gez has been recently estimated at 33 miles, of which 15 are through an inhabited, a well-clcared, and a well-cultivated country, and the next 18 , to the sca-coast, are through an uninterrupted forest.

The Russians have a settlement at $\Lambda$ shurada, not far from Gez. It is said they have offered to build a pier at the latter place, but that the Yersian Goverument has declined to ivail itself of the offer.

We bave now gone through, and $I$ fear in wearisome detail, the two -jentes which I had proposed to your consideration, as spccimens of the country between the Caspian and British India. This is, it will be observed, not only irrespective of any boundary line north of $A$ fghanistan, but of the Khaibar or other appronches to the strictly northwest fronticr. Although oue of the lines deseribed shows a few miles more than the other on paper, I think wo might by careful study of the country, and alteruative cross branches here and there, bring them Loth to much the same figure, a maximum of 1,800 and minimum of 1,500 miles. Sistan and Kandahar are the main features of the upper, as Karman and Banpur are of the lower ronte; but between Kandahar and the Indus, if not the Khojak and the Bolan, equally dangerous and more impracticable country intervenes by anything like a direct road; and between Bampur and Kurnchi full 600 miles are over, for the greater part, i most primitive and inhospitable tract. The Afghan. istan route, and claracter of the people in and around it, have been YoL, xyill. 
proved by troops as well as reported on by trafcllcrs, and such cxperiences are for Englishmen, military as well as general. It is to IIakran that I cannot but think more attention shonld be given; and lest future exigency demand advance of fronticr, let us at least know what are the pligsical fentures of the country cast and west of us, so that the corton may be thoroughly understood from the Sulimania range on our right hand to the scaboard of Makran on our left.

For my own part, and I speak with a ccrtain personal experience of a Perso-Afghan as a Perso-Baluch fronticr, I should like to see a railway from Herat, or some point in Central $A$ sia, to the Helmand, and from the Helmand to Gwadar; and though I cannot hope for that, yet I may hope to see the coast of Makran, from east to west, one of the links of the great line,-call it Enplrates Valley or by any other designation,--which must eventually connect London and Kurachi, or at lcast England and India.

\section{APPENDIX:}

Menorandum of the Thatci Supply on the Matiran Coast, or Letwera Karachi and Ormara; from Notes by Major F. J. Goldsmill, employed on a Special Mission in 1861-62.

Before rhe RiIn of Jusurr, 1802.:

\begin{tabular}{|c|c|c|c|}
\hline Names of stages. & \multicolumn{2}{|c|}{$\begin{array}{l}\text { Distance br } \\
\text { measureuleut. }\end{array}$} & Remarks. \\
\hline & II. & F. & \\
\hline 1. $\Pi u$ ubb & $1 ; 5$ & 4 & Good water from riser; supply abundant. \\
\hline 2. Kamarce.... & 17 & - & $\begin{array}{l}\text { Water from wells, brackisl but drinkable. Sup. } \\
\text { ply suficient for the day. MLore obtaicsic on } \\
\text { the line of march. }\end{array}$ \\
\hline 3. Sonmenuce... & 16 & 2 & $\begin{array}{l}\text { Water from wells, broclish but trinkable, and } \\
\text { suffeicnt. 'Tlese mar be dug at about } 6 \text { fect, } \\
\text { and are at first tolerable swcet. Irore procur- } \\
\text { able on the line of march from Farraren. }\end{array}$ \\
\hline 4. Buddo ...... & 22 & 1 & $\begin{array}{l}\text { Water sufficient and good from rirer. Wells on } \\
\text { the line of march. }\end{array}$ \\
\hline 5. Chus... & 11 & 5 & $\begin{array}{l}\text { Water from depressions of rirer bed; brackislt } \\
\text { and scarce. Well on the line of marcl, with } \\
\text { plot of grass and babul trees. }\end{array}$ \\
\hline 6. Por........ & 17 & 7 & $\begin{array}{l}\text { Water from wclls in the becl of rirer tolcrably } \\
\text { good and suflicient. }\end{array}$ \\
\hline 7. Hookec....... & 7 & - & $\begin{array}{l}\text { Watcr scarce and indifferent at the one well } \\
\text { arailable; but good water found at two miles' } \\
\text { distance tomard the sca, and again at four } \\
\text { miles W. at Supput. }\end{array}$ \\
\hline
\end{tabular}

* Old system of spclling retained, as in force twelre ycars ago. 
Before the Ray or Jayuar, 1862-continued.

\begin{tabular}{|c|c|c|c|}
\hline Names of stages. & \multicolumn{2}{|c|}{$\begin{array}{l}\text { Distance by } \\
\text { measuresnent. }\end{array}$} & Remurks. \\
\hline & $M$ & $\mathbf{P}$ & \\
\hline 8. Sungnl ...... & 12 & - & Water good and sufficient from wells dur in bed \\
\hline 9. Aghor....... & 11 & 2 & $\begin{array}{l}\text { Water from rirer good and abundant. Well at } \\
\text { Hiddlee ou line of marels. }\end{array}$ \\
\hline 10. Iramian $\ldots$ & 15 & 3 & $\begin{array}{l}\text { Water abundunt and good from Rirer Hingor ; } \\
\text { also procurable from same source on line of } \\
\text { march. }\end{array}$ \\
\hline 11. Shirkoonb... & 1.4 & 2 & $\begin{array}{l}\text { Watcr from rain collected in the "Troomb" or } \\
\text { nat ural basin at the foot of hills. Good aud } \\
\text { stuficient for the day. }\end{array}$ \\
\hline 12. Gaddligarh .. & 22 & 3 & $\begin{array}{l}\text { Water good aud sullicient from a "lioomb" } \\
\text { about lislf a mile distant; also procurable in a } \\
\text { small quantity at Jikkec Shor on the line of } \\
\text { muarch. }\end{array}$ \\
\hline 13. Manhcjec.... & 18 & 7 & $\begin{array}{l}\text { Watcr tolerabls good but barcly sufficient, from } \\
\text { depression in bed of river. Irocumble in small } \\
\text { quantitios from same source on line of march. }\end{array}$ \\
\hline 14. Orwarn..... & 10 & 4 & $\begin{array}{l}\text { Thater from wells brackish, but better obtainable } \\
\text { from wells at fire miles. distance. Sew well } \\
\text { dug, at } 4 \text { l fect, at Olmara. }\end{array}$ \\
\hline
\end{tabular}

Affre the Rits of Jaxuati.

\begin{tabular}{|c|c|c|c|}
\hline 13. Bussolc...... & 21 & 3 & $\begin{array}{l}\text { Water plentiful but mudds, from off-shoot of } \\
\text { rirer. IIore obtainable in abundance in the } \\
\text { neighbourhood or on line of march, owing to } \\
\text { Jate rains. }\end{array}$ \\
\hline 16. Kingarliee ... & 1.1 & 4 & $\begin{array}{l}\text { Water from Kwarrce stream sufficient; more on } \\
\text { the line of march. }\end{array}$ \\
\hline 17. Moondree.... & 15 & 1 & $\begin{array}{l}\text { Water from Moondreo hill stream. Good and } \\
\text { just sufficient. More on the line of march. }\end{array}$ \\
\hline 18. Jandi Shor.. & 20 & 4 & $\begin{array}{l}\text { Water from the "Shor" stream good and suffi. } \\
\text { cicnt. More on the line of narch, and at } \\
\text { Barngoli rirer a little W". of enmp. }\end{array}$ \\
\hline 19. P'usnce.. & 20 & - & $\begin{array}{l}\text { Water brackish from well, but good and abund- } \\
\text { nt from Shadikhror, at three miles' distance. } \\
\text { A bundant from rivers and depressions on line } \\
\text { of march. }\end{array}$ \\
\hline 20. Gorrana. & 9 & 5 & $\begin{array}{l}\text { Watcr from rain collected in liollows between } \\
\text { sand tills; at other times said to be procurable } \\
\text { from wells at } 3 \text { or } \& \text { fect. }\end{array}$ \\
\hline 21. Koonbec..... & 18 & 7 & $\begin{array}{l}\text { Water nudds, but suflicient from late rain; } \\
\text { abundant on line of march from lill streams } \\
\text { flowing frecle as we crossed. }\end{array}$ \\
\hline $\begin{array}{l}\text { 2:. Lakrce or } \\
\text { "Irurecr".. }\end{array}$ & 16 & - & $\begin{array}{l}\text { Water from depressions supplict by rain, good } \\
\text { and sufficient; more from Síwar river and } \\
\text { clscricre on line of mareh. }\end{array}$ \\
\hline 23. Baramba .... & 15 & 3 & $\begin{array}{l}\text { Water from rirer indifferent, but good and } \\
\text { abundant on line of march, owing to liate rain. }\end{array}$ \\
\hline 24. Gradar ..... & 20 & 1 & Water from wells good and sufficient. \\
\hline Total...... & 392 & 7 & \\
\hline
\end{tabular}


Su Hram Rawlixsox: I am sure you all must have listencd with great interest to the paper which has been just read by Sir Frederic Goldsnid. I have been over a great deal of the country, and can testify that all the descriptious are thoroughly accurate. One essential point which he has brought to our notice, is the absolute impracticability of the southern road for the mareh of an Army. A country where there are no supplies to be obtained, and where there is an entire want of water, cannot be thought of for the passare of an Army. We may therefore dismiss from on minds all fear of danger from that quarter. If any hostile demonstration shonld be made against India, it must be by the way of the northern line described, which would not, however, be so tortuous as that laid down on the map. A tortuous line has been drawn on the map and adhered to in the description, in order that it should have the authority of direct personal observation. For instance the road makes a considerable détou by way of Khozdar to Kelat, while the line through the Bolan pass is direct and much shorter. 'l'he road from that point to Kandahar, thence to Herat, and so on to Meshed, is all the way well supplicd. Kandahar itself is a very rich province, ind all the way to Herat, the road lies through a rich aud populous country. If any danger does approach India, undoubtedly it will be through that quarter, and I think, therefore, attention should be especially directed to Merv aud Herat. 'The question of a military invasion of India is, however, a very large subject, and one that it would be impossible to discuss on the present occasion. I simply wish to direct attention to the route by which alone an Army could march. Sir Fredcric Goldsmid has also spoken of a railway through Persia, which he hopes may sooner or later be constructed. If ever a railway, howerer, should pass through Persia, it will follow the Northern line, for the country along the Southem line, offers no cucouragement or facilities. In the course of time I think it probable that a line of railway will bo drawn from the Mediterrancan throngh Persia, by way of Teluran and Mreshed, and so on to Herat and Kandabar, and through Sinde to the Indus. I anl able to say, from personal observation, that from the western frontier of Persia to the Indus, there is absolutely no plysical difficulty whatever to be encountered; there is no pass, indeed, which an engineer wonld think anything of. The two Afohan passes of the Khojak and Bolan are nothing of any moment. The Bolan, sare for about a quarter of a milc, is so open that you might drire a coach and fonr the whole way; while the Khojak hills are conposed of a soft sandstone, which might bo cut through with the greatest ease; and besides, if necessary, the Thojak pass could be readily turned. We may lare to wait; but 50 or 100 years is, after all, not much in the history of the world; and within that time inere may be, ituiuk, such a railway constructed through Persin. I am sure you will allow me to return your thanks to Sir lirederic Goldsmicl, for his very able and interestiug papos: 